\title{
Thirty-year risk of cardiovascular disease in senior medical students - based on the StudHeart study
}

\author{
Robert Morawiec, Kamil Janikowski, Malgorzata Lelonek \\ Department of Cardiology, Chair of Cardiology and Cardiac Surgery, Medical University of Lodz, Poland \\ Kardiochirurgia i Torakochirurgia Polska 2016; 13 (2): 172-177
}

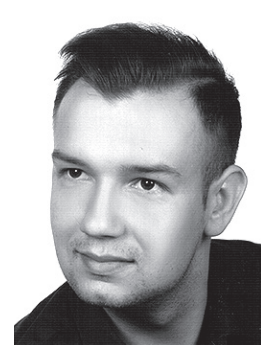

\begin{abstract}
Introduction: Long-term risk functions highlight the need of prophylaxis in youth before the first symptoms of cardiovascular disease (CVD) occur.

Aim: On the basis of data obtained in the StudHeart study, the aim of this report was to evaluate the 30-year risk of CVD based on the risk scale developed by the Framingham Heart Study (FHS).

Material and methods: Seven hundred and one students aged 22-27 (mean age: $24 \pm 1.42$ ) from the $5^{\text {th }}$ and $6^{\text {th }}$ year of the medical faculties of the Medical University of Lodz were included in the study. The StudHeart study was based on an anonymous survey comprising 12 questions. Based on the answers the authors evaluated the 30-year risk of CVD in each respondent using an on-line calculator that allows one to evaluate: general CVD risk including coronary death, myocardial infarction, coronary insufficiency, angina, ischemic stroke, hemorrhagic stroke, transient ischemic attack, peripheral artery disease, heart failure and hard CVD risk including coronary death, myocardial infarction and stroke.

Results: Elevated general 30-year CVD risk occurred in 23.18\% of students, while hard CVD risk was elevated in $16.91 \%$ of respondents. In both cases elevated risk occurred more often in men (general CVD risk: $43.46 \%$ male vs. $8.93 \%$ female, $p<0.001$ and hard CVD risk: $29.33 \%$ male vs. $8.19 \%$ female, $p<0.001)$. Elevation of the risk was mainly caused by overweight, obesity and smoking cigarettes.

Conclusions: Based on FHS 30-Year CVD risk, elevated risk occurred in almost one-fourth of students. Prophylactic actions should be performed, especially in men.
\end{abstract}

Key words: lifetime risk, risk factors, cardiovascular diseases, medical students.

\section{Introduction}

The prolongation of life expectancy which is observed nowadays confronts us with the need to create long-term risk scales in medicine. The 30-year risk of cardiovascular

\section{Streszczenie}

Wprowadzenie: Długoterminowe skale ryzyka podkreślają potrzebę prowadzenia profilaktyki wśród osób młodych przed wystąpieniem pierwszych objawów chorób sercowo-naczyniowych (ChSN).

Cel: Na podstawie danych z badania StudHeart celem badania była ocena 30-letniego ryzyka ChSN przy użyciu skali opracowanej przez Framingham Heart Study (FHS).

Materiat i metody: Do badania włączono 701 studentów w wieku 22-27 lat (średnio: $24 \pm 1,42$ roku) studiujących na V i VI roku wydziałów lekarskich Uniwersytetu Medycznego w Łodzi. Badanie oparto na anonimowej ankiecie zawierającej 12 pytań. Na podstawie uzyskanych odpowiedzi obliczono 30-letnie ryzyko wystąpienia ChSN dla każdego z badanych studentów przy użyciu kalkulatora dostępnego on-line, który umożliwia oszacowanie ogólnego ryzyka wystąpienia ChSN (ryzyko zgonu z przyczyn wieńcowych, zawału serca, dławicy piersiowej, niedokrwiennego i krwotocznego udaru mózgu, przemijającego napadu niedokrwiennego, niewydolności serca) oraz ryzyka wystąpienia ostrych ChSN (ryzyko zgonu z przyczyn wieńcowych, zawału serca, udaru mózgu).

Wyniki: U 23,18\% studentów stwierdzono podwyższone ogólne 30-letnie ryzyko ChSN, natomiast u 16,91\% ankietowanych ryzyko wystąpienia ostrych ChSN było zwiększone. W obu przypadkach podwyższone ryzyko stwierdzano częściej u mężczyzn (ogólne ryzyko wystąpienia ChSN: 43,46\% u mężczyzn vs 8,93\% u kobiet, $p<0,001$; ryzyko rozwoju ostrych ChSN: $29,33 \%$ u mężczyzn vs 8,19\% u kobiet, $p<0,001)$. Zwiększone ryzyko wynikało głównie z nadwagi, otyłości oraz palenia papierosów. Wnioski: Na podstawie skali 30-letniego ryzyka wystąpienia ChSN opracowanej przez FHS podwyższone ryzyko miała prawie 1/4 studentów. Działania profilaktyczne powinny być i prowadzone zwłaszcza wśród mężczyzn.

Słowa kluczowe: skala ryzyka, czynniki ryzyka, choroby sercowo-naczyniowe, studenci medycyny.

disease (CVD) prediction algorithm which is based on the Framingham Heart Study (FHS) and was published in 2009 [1] lives up to these expectations. The first results of the StudHeart study assessed the 10-year risk of diabetes mellitus type 2 among a group of 506 medical students [2].

Address for correspondence: Prof. Malgorzata Lelonek MD, PhD, FESC, Department of Cardiology, Chair of Cardiology and Cardiac Surgery, Medical University of Lodz, 251 Pomorska St, 90-213 Lodz, Poland, phone: +48 42201 43 18, e-mail: mlelonek@poczta.fm 


\section{Aim}

In this report we present the results of 30-year CVD risk among medical students based on the enlarged database of the StudHeart study. The aim of this report was to assess the 30-year CVD risk among senior medical students based on data obtained in the StudHeart study.

\section{Material and methods}

The StudHeart study was conducted from October to December in 2011 and 2012 among students of the $5^{\text {th }}$ and $6^{\text {th }}$ year of the medical degree course of the Faculty of Medicine and the Faculty of Military Medicine of the Medical University of Lodz. The exclusion criteria were as follows: students from other faculties, respondents over the age of 27 or below the age of 22 .

From the examined group of 710 senior medical students, 9 respondents refused to take part in the StudHeart study. All students included in the research filled out an anonymous survey obtaining all data needed to establish the 30-year risk of CVD based on the FHS with the simpler model of risk calculation using body mass index (BMI) instead of high-density lipoproteins ( $\mathrm{HDL}$ ) cholesterol and total cholesterol. The risk of 'hard' and 'general' CVD can be established using this algorithm. Predictors and diseases included in 'hard' and 'general' CVD risk are presented in Table I.

The population of interest in this model comprises individuals 20 to 59 years old free of CVD and cancer at baseline examination; hence respondents with hypertension (HA) were excluded from the analysis. The measurable and numerical data needed such as weight, height, and blood pressure (BP) were obtained from respondents only by appropriate questions in the StudHeart survey [2].

All data were collected in the computerized database. The 30-year risk of CVD was calculated for each respondent using the on-line calculator available at http://www. framinghamheartstudy.com.

The calculator evaluates the 30-year CVD risk and the 'normal risk' for each individual. The 'Normal risk' is the risk found in a comparable individual (age, sex) with the risk profile as follows: 1) non-smoker; 2) non-diabetic; 3) not treated for blood pressure; 4) systolic blood pressure of $125 \mathrm{~mm} \mathrm{Hg}$; and 5) BMI of $22.5 \mathrm{~kg} / \mathrm{m}^{2}$. All respondents with calculated 'Your risk' higher than the 'Normal risk' were separated as the group of elevated 30-year CVD risk. In the study by Gozdzik et al. the range of risk is classified as low (less than 12\%), intermediate ( $\geq 12 \%$ and $<40 \%)$ and high ( $40 \%$ or more) [3].

The StudHeart study was positively reviewed by the Bioethical Committee of Medical University of Lodz, Consent no. RNN/722/11/KB, October $18^{\text {th }}, 2011$.

\section{Statistical analysis}

The results were statistically analyzed. Elements of descriptive statistics were used to summarize the quantitative variables (arithmetic mean, median and standard deviation).
Nominal variables were characterized by cardinality and percentages. Independent groups of individuals (women vs. men) were compared by performing the Mann-Whitney $U$ test. In order to detect a statistically significant correlation between the groups the $\chi^{2}$ test of independenceor Cramer's $\checkmark$ test was used.

The statistical analysis was carried out using Statistica 10.0 PL software (StatSoft, Cracow, Poland). The results were considered statistically significant at $p<0.05$.

\section{Results}

Demographic characteristics of the studied population are given in Table II. The study included 701 students aged 22-27, comprising $70.52 \%$ of 994 senior medical students of the Medical University of Lodz in 2011 and 2012. There were more women than men. Most of the respondents had a BMI no higher than $25 \mathrm{~kg} / \mathrm{m}^{2}$. Overweight (BMI over $25 \mathrm{~kg} / \mathrm{m}^{2}$ ) was 8 times more frequent among men than women $(p<0.001)$. Differences in BMI according to gender are presented in Figure 1.

Only 81 of the respondents were smokers and most of them were men $(p=0.003)$. The onset of the smoking habit during studying at medical faculties occurred in more than one-third of smoking respondents. Further characteristics are presented in Table II. None of the students suffered from diabetes mellitus.

Results of the 30-year CVD risk are presented in Table III. Almost $25 \%$ of the respondents had general CVD risk ('Your risk' higher than 'Normal risk') elevated and more than $16 \%$ of students had the hard CVD risk elevated. Elevated general and hard CVD risk occurred more frequently in men than women $(p<0.001)$. Most students were in the group of low risk of both general and hard 30-year CVD risk (Table III). In the general risk group, only $2.56 \%$ of them had intermediate risk and $26 \%$ had the highest risk. In the hard 30-year CVD risk group, only $0.43 \%$ (3 men) of respondents had intermediate risk, and $16 \%$ had the highest risk. The elevation of 30-year CVD risk was mainly caused by overweight, obesity and smoking cigarettes.

\section{Discussion}

In this report we present the results of evaluating 30year CVD risk based on the FHS in senior medical students.

Tab. I. Characteristics of 30-year risk of CVD based on Framingham Heart Study [1]

Male sex, age, systolic blood pressure (SBP), use of antihypertensive treatment (yes/no), smoking,

Predictors diabetes mellitus, total cholesterol, HDL cholesterol, body mass index (BMI) (replacing lipids in a simpler model)

\begin{tabular}{ll}
\hline Hard CVD & Coronary death, myocardial infarction, stroke \\
\hline & $\begin{array}{l}\text { Coronary death, myocardial infarction, coronary } \\
\text { General }\end{array}$ \\
insufficiency, angina, ischemic stroke, hemorrhagic \\
stroke, transient ischemic attack, peripheral artery \\
disease, heart failure
\end{tabular}


Tab. II. Characteristic of studied population

\begin{tabular}{|c|c|c|c|c|c|c|c|}
\hline \multirow[t]{2}{*}{ Parameter } & \multicolumn{2}{|c|}{ Overall } & \multicolumn{2}{|c|}{ Women } & \multicolumn{2}{|c|}{ Men } & \multirow[t]{2}{*}{$P$-value } \\
\hline & $n$ & $\%$ & $n$ & $\%$ & $n$ & $\%$ & \\
\hline Cases $[n]$ & 701 & 100 & 412 & 58.77 & 289 & 41.23 & \\
\hline \multirow[t]{2}{*}{ Parameter } & \multicolumn{2}{|c|}{ Overall } & \multicolumn{2}{|c|}{ Women } & \multicolumn{2}{|c|}{ Men } & $P$-value \\
\hline & Mean \pm SD & Median & Mean \pm SD & Median & Mean \pm SD & Median & \\
\hline Age [years] & $24 \pm 1.42$ & 24 & $23.92 \pm 1.65$ & 24 & $24.10 \pm 2.06$ & 24 & 0.006 \\
\hline BMI $\left[\mathrm{kg} / \mathrm{m}^{2}\right]$ & $22.11 \pm 3.40$ & 21.97 & $20.57 \pm 3.37$ & 20.45 & $24.29 \pm 3.41$ & 24.29 & 0.001 \\
\hline \multirow[t]{2}{*}{ Parameter } & \multicolumn{2}{|c|}{ Overall } & \multicolumn{2}{|c|}{ Women } & \multicolumn{2}{|c|}{ Men } & $P$-value \\
\hline & $n$ & $\%$ & $n$ & $\%$ & $n$ & $\%$ & \\
\hline \multicolumn{8}{|l|}{ BMI [kg/m²]: } \\
\hline$>25$ & 110 & 15.69 & 16 & 3.88 & 94 & 32.53 & $<0.001$ \\
\hline $20-25$ & 405 & 57.77 & 219 & 53.16 & 186 & 64.36 & 0.005 \\
\hline$<20$ & 180 & 25.68 & 172 & 41.75 & 8 & 2.77 & $<0.001$ \\
\hline \multicolumn{8}{|c|}{ Diet - fruit and vegetables consumption: } \\
\hline Daily & 377 & 53.78 & 245 & 59.47 & 132 & 45.67 & $<0.001$ \\
\hline 2-3 times/week & 262 & 37.38 & 144 & 34.95 & 118 & 40.83 & NS \\
\hline A few times/month & 52 & 7.42 & 21 & 5.09 & 31 & 10.73 & 0.005 \\
\hline Less frequently & 10 & 1.43 & 2 & 0.49 & 8 & 2.77 & 0.029 \\
\hline \multicolumn{8}{|c|}{ Diet - fast food consumption: } \\
\hline Daily & 4 & 0.57 & 2 & 0.49 & 2 & 0.69 & NS \\
\hline 2-3 times/week & 49 & 6.99 & 14 & 3.40 & 35 & 12.11 & $<0.001$ \\
\hline A few times/month & 347 & 49.50 & 192 & 46.60 & 155 & 53.63 & NS \\
\hline Less frequently & 301 & 42.94 & 204 & 49.51 & 97 & 33.57 & $<0.001$ \\
\hline \multicolumn{8}{|c|}{ Alcohol consumption at least one beer or 50 gs of vodka: } \\
\hline Yes & 656 & 93.58 & 379 & 91.99 & 277 & 95.85 & 0.040 \\
\hline No & 44 & 6.28 & 33 & 8.01 & 12 & 4.15 & \\
\hline Daily & 11 & 1.68 & 2 & 0.53 & 9 & 3.25 & 0.014 \\
\hline 2-3 times/week & 123 & 18.75 & 39 & 10.29 & 83 & 29.96 & $<0.001$ \\
\hline A few times/month & 338 & 51.52 & 207 & 54.62 & 131 & 47.29 & NS \\
\hline Less frequently & 185 & 28.20 & 131 & 34.56 & 54 & 19.50 & $<0.001$ \\
\hline \multicolumn{8}{|l|}{ Smoking: } \\
\hline Yes & 81 & 11.57 & 35 & 8.50 & 46 & 15.92 & 0.003 \\
\hline No & 619 & 88.43 & 377 & 91.50 & 243 & 84.08 & \\
\hline \multicolumn{8}{|l|}{ Onset of smoking: } \\
\hline$<5$ years & 29 & 35.80 & 5 & 14.29 & 24 & 52.17 & $<0.001$ \\
\hline$\geq 5$ years & 52 & 64.20 & 30 & 85.71 & 22 & 47.83 & \\
\hline \multicolumn{8}{|c|}{ Physical activity at least 30 minutes without a break: } \\
\hline Daily & 93 & 13.27 & 36 & 8.73 & 57 & 19.72 & $<0.001$ \\
\hline 2-3 times/week & 283 & 40.37 & 153 & 37.14 & 130 & 44.98 & 0.037 \\
\hline A few times/month & 226 & 32.24 & 153 & 37.14 & 73 & 25.26 & $<0.001$ \\
\hline Less frequently & 98 & 13.98 & 70 & 16.99 & 28 & 9.69 & 0.006 \\
\hline
\end{tabular}


The results show that most of the medical students invoIved in the study were at low risk of CVD. The studied population consisted of similar individuals (young medical students) who had almost completed the course of the faculty of medicine. Thus, they had all gained complete knowledge of modifiable risk factors of CVD. Nevertheless, our study shows that almost $25 \%$ of them had the 30-year CVD risk elevated (general CVD 'Your risk') in comparison to completely healthy individuals ('Normal risk'). The elevated risk occurred mainly in men. Despite the fact that the vast majority of examined students were in the group of low risk (according to Gozdzik et al.), it seems important to underline that in the young population with a high level of health awareness (medical students) there are some students in the group of intermediate 30-year CVD risk level and most of them are men. This fact emphasize the importance of using long-term risk functions at every age and the need to create such risk functions for easy use worldwide, as for example 30-year CVD risk based on the FHS.

Grundy et al. underline the need and importance of long-term prevention in young adults to minimize the future occurrence of coronary heart disease [4]. As the study states, short-term risk evaluation may not point out the need to reduce modifiable risk factors in youth while the risk estimated by long-term risk functions could be unacceptably high. Thus the elevated long-term risk is an early warning of a need of changes in lifestyle in these patients, for example inappropriate eating habits, overweight, smoking cigarettes, and an inadequate level of physical activity. Changing lifestyle is often the easiest way to prevent CVDs and can reduce the long-term risk.

The results of our research show that elevated risk occurred more often in students with overweight or obesity. Elevated $\mathrm{BMI}$ (> $25 \mathrm{~kg} / \mathrm{m}^{2}$ ) seems to be the greatest risk factor in the studied population. Nowadays, one of the most important problems of the world population is the outbreak of the obesity epidemic. According to the World Health Organization worldwide obesity has doubled since 1980 [5]. Excessive body weight leads to elevated CVD risk and mortality overall [6]. Moreover, the results of the StudHeart study show that dietary habits of some medical stu-

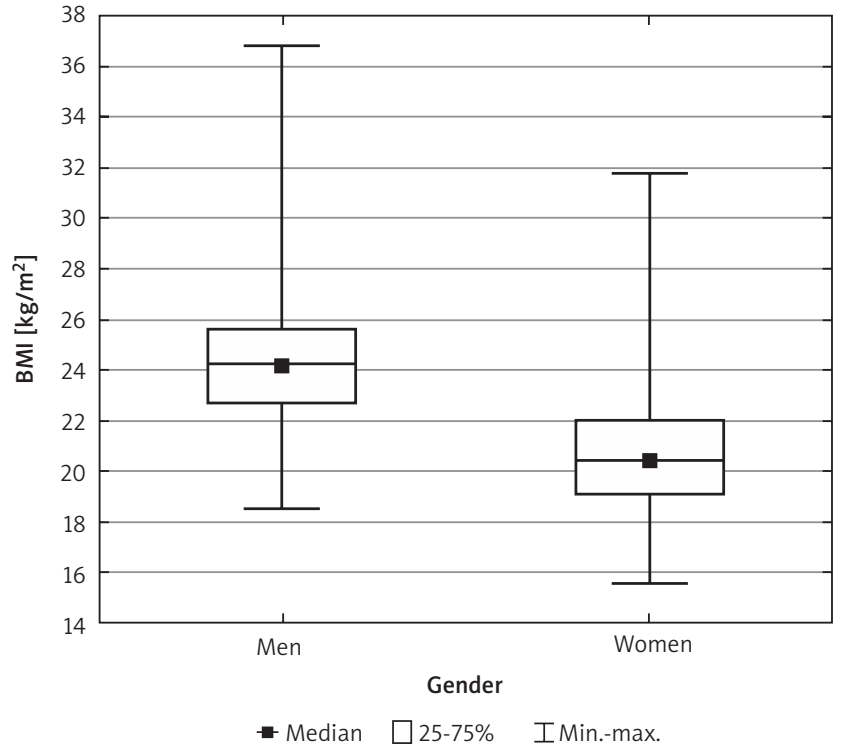

Fig. 1. Differences in BMI according to gender $(p=0.001)$

dents are reflected not only in elevated CVD risk but also the risk of type 2 diabetes mellitus (T2DM) [2]. More than $15 \%$ of medical students have BMI over $25 \mathrm{~kg} / \mathrm{m}^{2}$, but more worrying is the fact that almost one-third of men in the StudHeart study are overweight $32.53 \%$ of men vs. $3.88 \%$ of women, $p<0.001)$. This observation is similar to many studies worldwide. For example, in the research conducted among 989 third-year medical students in Crete, 39.5\% of men and $23.3 \%$ of women were overweight or obese: BMI $25-29.9 \mathrm{~kg} / \mathrm{m}^{2}-34.4 \%$ of men and $19.9 \%$ of women ( $p<$ $0.001)$; and $\mathrm{BMI}>30 \mathrm{~kg} / \mathrm{m}^{2}-5.1 \%$ of men and $3.4 \%$ of women $(p<0.001)$ [7]. When comparing the results of the StudHeart study to the study conducted by Kardjalik et al. in 2010/2011 among 280 students of the Medical University of Lodz, BMI over $25 \mathrm{~kg} / \mathrm{m}^{2}$ was also more common among men than women (26.6\% vs. $6.5 \%$ ). Moreover, $45 \%$ of students reported fast-food consumption a few times per month and $2.5 \%$ a few times per week [8]. It is worrying that in comparison to our results fast food consumption

Tab. III. Overall results of 30-year CVD risk in studied population

\begin{tabular}{|c|c|c|c|c|c|c|c|}
\hline \multirow[t]{2}{*}{ Variable } & \multicolumn{2}{|c|}{ Overall } & \multicolumn{2}{|c|}{ Women } & \multicolumn{2}{|c|}{ Men } & \multirow[t]{2}{*}{$P$-value } \\
\hline & $n$ & $\%$ & $n$ & $\%$ & $n$ & $\%$ & \\
\hline \multicolumn{8}{|l|}{ General 30-year CVD risk: } \\
\hline 'Your risk' > 'normal risk' & 159 & 23.18 & 36 & 8.93 & 123 & 43.46 & $<0.001$ \\
\hline Low risk (<12\%) & 683 & 97.44 & 411 & 99.76 & 272 & 94.12 & \\
\hline Intermediate risk ( $\geq 12 \%$ and $<40 \%)$ & 18 & 2.56 & 1 & 0.24 & 17 & 5.88 & \\
\hline High risk (>40\%) & 0 & 0 & 0 & 0 & 0 & 0 & \\
\hline \multicolumn{8}{|l|}{ Hard 30-year CVD risk: } \\
\hline 'Your risk' > 'Normal risk' & 116 & 16.91 & 33 & 8.19 & 83 & 29.33 & $<0.001$ \\
\hline Low risk $(<12 \%)$ & 698 & 99.57 & 412 & 100 & 286 & 98.96 & \\
\hline Intermediate risk ( $\geq 12 \%$ and $<40 \%)$ & 3 & 0.43 & 0 & 0 & 3 & 1.04 & \\
\hline High risk (> 40\%) & 0 & 0 & 0 & 0 & 0 & 0 & \\
\hline
\end{tabular}


among students is increasing $(49.5 \%$ a few times a month and $7.56 \%$ at least $2-3$ times a week in the StudHeart study). In another study conducted among 610 students of the Medical University of Lodz in 2007 excessive body weight was also more common among men than women (35.2\% vs. 5.7\%) [9]. The results mentioned above are in agreement with the results of the StudHeart study. Bad dietary habits among medical students are also present among medical doctors, as was found in the study of Niedźwiedzka et al., where $9.4 \%$ of 150 medical doctors reported fast-food consumption a few times a week [10].

Another study conducted in 2010 among students of Bialystok University of Technology (Poland) showed excessive bodyweight in $21.69 \%$ of men and $4.48 \%$ of women [11]. Compared with the StudHeart study, overweight is more common among medical students. Body mass reduction not only leads to reduced CVD risk but also brings clinical benefits for patients. A meta-analysis of 25 randomized clinical trials showed that for each kilogram of weight loss in obese and overweight patients, the systolic and diastolic blood pressure decreased by about $1 \mathrm{~mm} \mathrm{Hg}$ [12]. Moreover, lifestyle modifications can substantially delay or even prevent the occurrence of hypertension [13].

Besides overweight, the next risk factor of CVD that should be mentioned as the cause of CVD risk elevation in the StudHeart population is smoking cigarettes. The StudHeart study shows that more than every tenth student smokes cigarettes. Most of the smokers are men (15.92\% of men vs. $8.50 \%$ of women; $p=0.003$ ). In comparison, in a study conducted in Greece more than two decades ago among medical, dental and nursing students $(n=832)$ the percentage of smokers was at a comparable level to the StudHeart study (respectively $10.1 \%$ vs. $11.57 \%$ ) [14].

The results of the Global Health Professions Student Survey (GHPSS) that was conducted among medical students in 47 countries and Gaza Strip/West showed that over $20 \%$ of the students currently smoked cigarettes (results obtained in 26 sites) [15]. In 37 sites the percentage of smoking students was higher in men than in women. Similar observations were made in our study. In spite of the wide knowledge gained during medical studies of the risks associated with smoking cigarettes, the percentage of students addicted to nicotine seems to be excessive. However, fewer students are addicted to nicotine in the StudHeart population in comparison to the group who have taken part in GHPSS. Fewer students smoke cigarettes in the StudHeart population in comparison to studies conducted among other medical faculties in Poland. Addiction to nicotine is more common among medical students of the Medical University of Wroclaw (18\%) [16] and Gdansk Medical University (29\%) [17] than respondents of the StudHeart study.

Reducing risk factors in youth is very important in order to reduce the occurrence of CVD. An example of the role of prophylaxis focused on reducing risk factors is shown in the report by Vartiainen et al. [18]. The authors reported $80 \%$ reduction of coronary mortality in Finland in a 35-year period (since 1972), and as the main cause of this trend they underline the role of a great decline of risk factor levels. In a randomized controlled trial of multifactorial lifestyle modifications Ziv et al. state that broad lifestyle improvement results in an improved glucose/lipid profile and significant reduction of blood pressure [19]. Moreover, data from 5 prospective, large population-based studies show that lifestyle free of three major risk factors of CVD (serum cholesterol level, blood pressure, smoking) leads to longer lifetime expectancy [20]. However, young people are usually not aware of the danger. The awareness of medical students, though higher than in the general population, seems still insufficient. The use of long-term risk scales, such as 30-year risk of CVD based on the FHS, could bring better results in reducing risk factors. It derives from the fact that assessing short-term risk in youth could show a very low level of the risk, while the long-term risk could be importantly elevated. The 30-year risk scale enlightens youth on the real impact of improper lifestyle habits on their future. Moreover, they might be more likely to make necessary lifestyle changes if they know their long-term risk of CVD, including coronary death, myocardial infarction and stroke.

Even though CVD risk functions based on the FHS are very useful and popular worldwide, they are not free of disadvantages. Hippisley-Cox et al. point that the CVD risk scores based on the FHS may overestimate the risk in contemporary northern European populations due to the fact that the FHS was developed during a period with a high level of CVD incidents in America [21]. Moreover, the FHS risk function does not take into consideration family history of CVD as a risk factor. The authors also state that the population of the FHS is white in most cases and the risk may be overestimated in ethnically varied populations. However, in the case of the StudHeart study population, which is entirely white, this point seems irrelevant.

The main limitation of the StudHeart study is the method of collecting the data - the anonymous survey itself. The authors cannot be certain whether all of the respondents' answers are consistent with the actual status. Despite the fact that the risk level obtained by the on-line calculator of 30-year CVD ('Your risk') is given with the 'Normal risk' for each individual to compare, the next important limitation of the study is the lack of a control group (for example students from other faculties or universities). Comparison of results from the control group and the studied population could give the answer to the still unanswered question about the influence of medical knowledge gained during studying medicine on the changes in lifestyle and awareness of the risk of CVDs in medical students.

\section{Conclusions}

Despite the fact that most of the students are in the low risk group, almost one-fourth of them have the general 30year CVD risk elevated and one-sixth have the hard CVD risk elevated, in comparison to individuals with an optimal risk profile ('Normal risk'). Among this population, elevated risk occurs particularly among men. The main risk factors causing elevated CVD risk in students are overweight, obesity 
and smoking cigarettes. Evaluating long-term risk and prophylactic actions should be performed, especially in men.

\section{Acknowledgments}

The data were collected within the activities of the Students' Research Group at the Department of Cardiology and Cardiac Surgery of the Medical University of Lodz. We would like to thank Magdalena Wirtek and Jaroslaw Zawisza for assistance in collecting the data.

The study was presented at the "JUVENES PRO MEDICINA" 2013 in Lodz - the $51^{\text {st }}$ Polish and $9^{\text {th }}$ International Training and Scientific Conference of Students' Scientific Societies and Junior Doctors. The study was awarded with the $1^{\text {st }}$ prize in the Cardiology Session.

\section{Disclosure}

Authors report no conflict of interest.

\section{References}

1. Pencina MJ, D’Agostino RB, Larson MG, Massaro JM, Vasan RS. Predicting the 30-year risk of cardiovascular disease. The Framingham Heart Study. Circulation 2009; 119: 3078-3084.

2. Morawiec R, Janikowski K, Zawisza J, Lelonek M. StudHeart-diabetes mellitus t.2 risk factors in senior medical students. Centr Eur J Med 2013; 8: 608-617.

3. Gozdzik A, Salehi R, O'Campo P, Stergiopoulos V, Hwang SW. Cardiovascular risk factors and 30-year cardiovascular risk in homeless adults with mental illness. BMC Public Health 2015; 15: 165.

4. Grundy SM, Pasternak R, Greenland P, Smith S, Fuster V. Assessment of cardiovascular risk by use of multiple-risk-factor assessment equations A Statement for Healthcare Professionals From the American Heart Association and the American College of Cardiology. Circulation 1999; 100: 1481-1492.

5. Obesity and overweight [Internet]. World Health Organization; 2012 [cited 2015 March 15]. Available from: http://www.who.int/mediacentre/factsheets/ fs311/en/.

6. Jung RT. Obesity as a disease. Br Med Bull 1997; 53: 307-321.

7. Bertsias G, Mammas I, Linardakis M, Kafatos A. Overweight and obesity in relation to cardiovascular disease risk factors among medical students in Crete, Greece. BMC Public Health 2003; 3: 3.
8. Kardjalik K, Bryła M, Maniecka-Bryła I. Nutrition-related health behaviors and prevalence of overweight and obesity in a group of university students. Probl Hig Epidemiol 2012; 93: $71-79$ (in Polish).

9. Trafalska E, Grzybowski A. Risk factors in obesity and other obesity-related diseases among Lodz Medical University students. Żyw Czł Metab 2007; 34 965-971 (in Polish) [Abstract].

10. Niedźwiedzka M, Grzybowski A. Nutrition in a selected group of physicians. Probl Hig Epidemiol 2011; 92: 973-976 (in Polish).

11. Zuzda J, Latosiewicz R, Półjanowicz W. Examination of obesity among students of Bialystok University of Technology and University of Economics. Ekonomia i Zarządzanie 2010; 2: 74-80 (in Polish).

12. Neter JE, Stam BE, Kok FJ, Grobbee DE, Geleijnse JM. Influence of weight reduction on blood pressure. A meta-analysis of randomized controlled trials. Hypertension 2003; 42: 878-884.

13. Frisoli TM, Schmieder RE, Grodzicki T, Messerli FH. Beyond salt: lifestyle modifications and blood pressure. Eur Heart J 2011; 32: 3081-3087.

14. Najem GR, Passannante MR, Foster JD. Health risk factors and health promoting behavior of medical, dental and nursing students. J Clin Epidemiol 1995; 48: 841-849.

15. Warren CW, Sinha DN, Lee J, Lea V, Jones NR. Tobacco use, exposure to secondhand smoke, and cessation counseling among medical students: crosscountry data from the Global Health Professions Student Survey (GHPSS), 2005-2008. BMC Public Health 2011; 11: 72.

16. Poreba R, Gac P, Zawadzki M, Poreba M, Derkacz A, Pawlas K, Pilecki W, Andrzejak R. Styl życia i czynniki ryzyka chorób układu krążenia wśród studentów uczelni Wrocławia. Pol Arch Med Wewn 2008; 118: 102-110 (in Polish).

17. Zarzeczna-Baran M, Wojdak-Haasa E. Wiedza studentów Akademii Medycznej w Gdańsku o niektórych elementach stylu życia. Probl Hig Epidemiol 2007; 88: 55-59 (in Polish).

18. Vartiainen E, Laatikainen T, Peltonen M, Juolevi A, Männistö S, Sundvall J, Jousilahti P, Salomaa V, Valsta L, Puska P. Thirty-five-year trends in cardiovascular risk factors in Finland. Int J Epidemiol 2010; 39: 504-518.

19. Ziv A, Vogel O, Keret D, Pintov S, Bodenstein E, Wolkomir K, Doenyas K, Mirovski Y, Efrati S. Comprehensive Approach to Lower Blood Pressure (CALM-BP): a randomized controlled trial of a multifactorial lifestyle intervention. J Hum Hypertens 2013; 27: 594-600.

20. Stamler J, Stamler R, Neaton JD, Wentworth D, Daviglus ML, Garside D, Dyer AR, Liu K, Greenland P. Low risk-factor profile and long-term cardiovascular and noncardiovascular mortality and life expectancy findings for 5 large cohorts of young adult and middle-aged men and women. JAMA 1999; 28: 2012-2018.

21. Hippisley-Cox J, Coupland C, Vinogradova Y, Robson J, May M, Brindle P. Derivation and validation of QRISK, a new cardiovascular disease risk score for the United Kingdom: prospective open cohort study. BMJ 2007; 335: 136. 